\title{
Foreign and Bilingual Language Education in the UK and Spain: A Study of Similarities and Differences
}

\author{
Francisco Javier Palacios-Hidalgo, Cristina A. Huertas- \\ Abril, $\mathbf{M}^{\mathrm{a}}$. Elena Gómez-Parra \\ University of Córdoba
}

Correspondence concerning this article should be addressed to Francisco Javier Palacios-Hidalgo, University of Córdoba, Av. San Alberto Magno s/n, Córdoba, Spain, 14004.

E-mail: francisco.palacios@uco.es

\begin{abstract}
Language learning, as a means to promote intercultural awareness and communication as well as to help citizens prosper professionally, is one of today's main goals of educational systems around the world. In Europe, several guidelines have been published, and significant efforts have been devoted to encouraging the development of the quality of foreign and bilingual language education to improve citizens' communicative skills. Although there were attempts to foster foreign language proficiency in some parts of the United Kingdom between the 1990s and the early 2000s, the country has not traditionally considered languages among its educational priorities. Nonetheless, Brexit seems to have increased the need to learn languages in the country. In some other European countries, however, Content and Language Integrated Learning (CLIL), an additive bilingual approach, has been implemented since the early 2000 . Considering that the nations in the United Kingdom and the regions in Spain have the freedom to organise educational affairs, an analysis of the provision of foreign and bilingual language education in the United Kingdom and Spain appears relevant. This paper presents the results of a systematic review of 2012-2020 literature in the field of foreign and bilingual language education in both contexts. The differences that exist within the United Kingdom concerning foreign language teaching are discussed, and information in relation to the provision of CLIL in some Spanish regions is also examined. The findings show that foreign language teaching is provided across the United Kingdom, whereas bilingual education is offered in the form of Welsh-, Irish-, and Gaelic-medium education mainly, although CLIL is also implemented in England.
\end{abstract}

Keywords: language learning policies, bilingual education policies, Content and Language Integrated Learning (CLIL), comparative study, systematic literature review, foreign language education

\section{Introduction}

The $21^{\text {st }}$ century has triggered profound changes in society. These have provided human beings with a wide range of resources for accessing information and knowledge, but they have also posed new social demands, such as the ability to communicate with people in an increasingly multilingual and multicultural world. In this sense, being competent in at least one modern foreign language (MFL) is considered a key factor "for social inclusion, mutual understanding and professional development" ${ }^{1}$. Furthermore, the growing requirement that schools in Europe are facing in order to confront the culturally diverse classroom reality is compelling teachers and students to become intercultural and global citizens (Smolcic \& Katunich, 2017).

\footnotetext{
${ }^{1}$ Council of Europe. (2018b). Common European framework of reference for languages: Learning, teaching, assessment. Companion volume with new descriptors. Council of Europe.
} 
In this context, and following the Council of Europe ${ }^{2}$ and the European Commission ${ }^{3,4}$ guidelines, European education bodies have started to develop bilingual (and multilingual) education programs (i.e., education using more than one language of instruction; García, 2009, p. 17) aiming to promote linguistic diversity and intercultural communication. Among the existing approaches to bilingual education, Content and Language Integrated Learning (CLIL) has grown in the past 40 years (Bower, 2021; European Commission ${ }^{5}$ ), providing content instruction through an MFL so as to reinforce language learning and develop learners' intercultural awareness and global integration (Coyle et al., 2010). Inspired by the Canadian language immersion programs, North American bilingual education, and European international schools (Pérez-Cañado, 2012), CLIL "is a dual-focused educational approach in which an additional language is used for the learning and teaching of both content and language [simultaneously]", which are "interwoven, even if the emphasis is greater on one or the other at a given time" (Coyle et al., 2010, p. 23). According to Dalton-Puffer and Smit (2013), unlike other forms of bilingual education, CLIL is an additive bilingual approach in which the language of instruction is an MFL instead of a second national language and is usually implemented after the learners are competent in their mother tongue. Likewise, the language continues to be offered as an MFL-specific subject together with CLIL lessons and teachers "are normally non-native speakers of the target language and are typically content rather than foreign-language specialists" (Dalton-Puffer \& Smit, 2013, p. 546). Other clear differences between CLIL and any other type of bilingual education are discussed by Cenoz et al. (2014): CLIL implementation starts once learners have acquired a certain level of literacy in their first language, whereas bilingual education begins earlier. In CLIL, students are taught the language to acquire a certain command of the target language that allows them to communicate, while the primary goal of other types of bilingual education is native-like proficiency. As for the target language, in bilingual education it is normally a second one (e.g., co-official languages in bilingual communities) as opposed to CLIL, in which it normally takes place through a foreign language. In this article, the term 'CLIL' is used to refer to the form of additive bilingual education associated with CLIL, whereas 'bilingual education' is reserved for the bilingual education that is provided in bilingual communities (e.g., Wales or Catalonia).

However, bilingual education is not a new phenomenon despite its recent popularity. It has been developed in countries like Belgium, Luxembourg, and Finland for decades (Horner \& Weber, 2015; Izquierdo, 2017; Mehisto \& Genesee, 2015). It must be borne in mind that the situation in these three countries is quite different from others in Europe since establishing bilingual education in territories with more than one official language does not present the same challenges as introducing additive bilingual education in monolingual and/or larger countries, such as the United Kingdom (UK) and Spain, the focus of this article.

This paper examines some similarities and differences between the provision of foreign and bilingual language education in the UK and in Spain. To do so, a systematic review of scientific literature published between 2012 and 2020 was followed to answer the following research questions: (RQ1) What are the main characteristics of the bilingual programs (if any) implemented in the UK? and (RQ2) What are the similarities and differences between the language policies of the UK and Spain?

\section{An Overview of Foreign and Bilingual Language Education in the UK and Spain}

Despite receiving a large number of immigrants every year (European Commission ${ }^{6}$ ), the UK has not traditionally considered languages among its main educational priorities due to the power of English as the new lingua franca (Lanvers, 2014; Lanvers \& Coleman, 2017; Lo Bianco, 2014). This high immigration flow has been worldwide for decades (Oakland, 2016), with over 300 languages being spoken in London at the beginning of the century (Baker \& Eversley, 2000), with Bengali and Polish some of the most widely spoken in the city as well as the rest of England and in Wales?.

${ }^{3}$ European Commission. (1995). White paper on education and training - Teaching and learning - Towards the learning society. Commission of the European Communities.

${ }_{4}$ European Commission. (2003). Promoting language learning and linguistic diversity: An action plan $2004-2006$. Commission of the European Communities.

${ }^{5}$ European Commission. (2017). Key data on teaching languages at school in Europe. 2017 edition. Eurydice report. Publications office of the European Union.

${ }^{6}$ European Commission. (2020). 2019 annual report on intra-EU labour mobility. Final report January 2020. Publications office of the European Union.

7 Office for National Statistics. (2013, March 4). Language in England and Wales: 2011. https://bit.ly/3dAapzJ
} 
The UK is not the only country with difficulties in language learning. Other countries with similar issues know they must prioritise English as the language to be learnt, which is not the case in the UK (Kelly, 2018). However, Brexit seems to be posing demands for citizens of the UK in terms of language and intercultural skills. As Holmes (2018) explains, "the implications of leaving the EU [...] would mean the likelihood of increased bureaucracy" which would imply that the UK's "capacity in language skills and cultural competence will be seriously put to the test" (p. 63). Thus, urgent action needs to be taken in the country in this sense.

There were several initiatives in the UK from 1990 to 2010 to foster language learning and even teacher's continuous training (usually referred to as 'continuing professional development' in the UK) in the field of languages in the country, which were lauded across Europe. In this light, it is worth mentioning the Centre for Information on Language Teaching and Research (CILT) established in 1966, which played a special role in supporting MFL learning and teaching. CILT supported language teaching from 1966 to 2011 by promoting research in the field, creating materials to help teachers, and monitoring trends in language teaching, among other actions (McLelland, 2018). Likewise, the establishment of specialist Language Colleges in 1995 and the National Languages Strategy developed in England from 2002 to $2010^{8}$, although there are attempts to develop a new one ${ }^{9}$, provided not only teachers with access to information, advice, and training about language teaching but also set out structured and progressive objectives for MFL teaching for students, who were granted access to a wide range of languages (Dobson, 2018). Other more recent government-funded initiatives include the Teaching Schools Council review ${ }^{10}$, the National Centre for Excellence for Language Pedagogy ${ }^{11}$, and the Mandarin Excellence Programme ${ }^{12}$.

There is a "widely held - if not undisputed - view that the UK is lacking in the necessary language skills for the future, partly because of the status of English as the language of international communications" (Tinsley \& Board, 2013, p. 3). Although this 'English is enough' myth is not exclusive to the UK (for instance, English monolingual practices seem to prevail at US universities and at a macro institutional level [Britton, 2021] and even in Spanish regions [Relaño-Pastor, 2015]). Lanvers (2017a) tries to explain that the main reasons for the disinterest in languages among learners in the UK tend to be connected to sociocultural factors. The author emphasises three main reasons for such a lack of interest in languages: (i) the unrealistic idea of the global importance of English in the country (Schulzke, 2014); (ii) the 'climate of negativity' and the consequent loss of confidence of language learners in the UK derived from the debate on their poor language skills (Graham \& Santos, 2015); and (iii) the withdrawal of the UK from the European Union (Lanvers, 2017a).

It is worth mentioning though that in Wales and Scotland, local government and education institutions are concerned with the MFL provision and with the protection of their minority heritage languages. In Wales, for instance, efforts have been translated into a five-year plan that proposes "studying English, Welsh and at least one MFL from primary to examination level" ${ }^{13}$. Similarly, Scotland is developing the 1+2 Language Strategy to promote the learning of the mother tongue in addition to two MFLs ${ }^{14}$, although there are also language immersion programs in which Gaelic is used as the medium of instruction (MacQuarrie \& Lyon, 2019).

In the Spanish context, Izquierdo (2017) explains that foreign language learning and teaching changed in the last decade of the $20^{\text {th }}$ century after the publication of the European Commission's White paper on education and training, which proposed that secondary education students should start studying "certain subjects in the first foreign language learned" (European Commission, 1995, p. 47), setting the path for an innovative foreign language teaching method in which the foreign language could also be used for the teaching of content subjects. Spanish education bodies have directed multiple efforts to apply the European Commission's guidelines in order to promote MFL learning, linguistic diversity, and intercultural awareness by developing bilingual programs based on CLIL. Bilingual education in the monolingual regions of the country began in 1996 with the

\footnotetext{
8 Department for Education and Skills. (2002). Languages for all: Languages for life. A Strategy for England. Department for education and skills.

9 The British Academy. (2020). Towards a national languages strategy: Education and skills. The British Academy, Arts and Humanities Research Council, Association of School and College Leaders, The British Council, Universities UK. https://bit.ly/3bqpMYT

${ }^{10}$ Teaching Schools Council. (2016). Modern Foreign Languages Pedagogy Review. Teaching Schools Council. https://bit.ly/37wGqVN

${ }^{11}$ Department for Education. (n. d.). National Centre for Excellence for Language Pedagogy. Department for Education.

12 Department for Education. (2018). Mandarin Excellence Programme. Department for education.

${ }^{13}$ Welsh Government. (2015). Global futures. A plan to improve and promote modern foreign languages in Wales 2015-2020. Welsh Government. https://bit.ly/2meNAcJ

${ }^{14}$ Scottish Government. (2012). Language learning in Scotland: A 1+2 approach. Report and recommendations. Scottish Government. https://bit.ly/2mon9UM
} 
agreement between the Spanish Ministry of Education and British Council, which was developed to promote English language learning among Spanish students ${ }^{15}$ (MEC/British Council, 1996) and set the base for bilingual education (trilingual in the case of bilingual areas) in Spain. The agreement, which is still in force in more than 80 primary schools and more than 50 secondary schools, aims to develop an English-Spanish integrated curriculum from kindergarten to secondary education (Dobson et al., 2010).

The UK and Spain are somewhat similar in administrative terms. The nations in the UK have the competence to organise educational affairs. Spanish regions (known as 'autonomous communities') also have the freedom to regulate their own education (and language education) policies, while still using LOMLOE, the country's education law, as a base (Ley Orgánica 3/2020). This has resulted in different methods of implementing bilingual education across the country, with teacher requirements, languages of instruction, and subjects taught through bilingual education varying from one autonomous community to another. For instance, the situations in the Community of Madrid and Community of Andalusia, two of the forerunners of bilingual programs in Spain, differ; for instance, educators participating in bilingual education need to have a certified C1 (i.e., advanced) level of the language in Madrid while a B2 (i.e., upper-intermediate) level is required in Andalusia $^{16,17}$.

Both countries share sociocultural aspects as well. The UK and Spain both have a wide array of minority and majority languages spoken among their citizens. In Spain, not only are the co-official languages (i.e., Basque, Catalan, Galician, and Valencian) spoken but minority languages such as Aragonese, Aranese, Asturian, and Leonese are as well. Likewise, Welsh, Scottish-Gaelic (Gàidhlig), Scots, and Irish (Gaeilge), together with other minority languages (e.g., Ulster-Scots and other regional ones like Cornish) are spoken in the UK apart from English $^{18}$. Spain and the UK also face separatist challenges in some parts of their territories, which are partly linked to their linguistic reality; for instance, in Catalonia, Catalan is regarded as a factor for identity construction (Escolano, 2021), whereas a similar situation exists in Northern Ireland with Irish (Dunlevy, 2020).

Although there may be European countries implementing bilingual education whose students have better academic and linguistic results (such as Canada, Belgium, or Luxembourg; see Izquierdo, 2017), the similarities between Spain and the UK previously discussed makes it relevant to compare them.

\section{Materials and Methods}

This study follows a systematic literature review. It analyses empirical and theoretical works and aims at collecting information about language and bilingual education provision in the UK. The review also seeks to compare the situation in the UK and Spain in the field of MFL and bilingual programs considering their similarities.

In order to reduce bias in the review, the following sub-sections and Figure 1 describe the research protocol followed, which was developed according to Kitchenham et al.'s (2009) and Okoli’s (2015) guidelines and stages, namely: (i) pre-test literature review, (ii) initial search, (iii) literature selection, and (iv) data extraction, analysis, and synthesis.

\footnotetext{
${ }^{15}$ MEC/British Council. (1996). Documento técnico de mínimos (I) necesarios para el adecuado desarrollo de la experiencia de educación bilingüe que se realiza en los centros educativos adscritos al convenio entre el Ministerio de Educación y Cultura y el British Council de España. MEC/British Council.

${ }^{16}$ Comunidad de Madrid. (2019). Madrid, comunidad bilingüe 2018-2019 [Madrid, bilingual community 2018-2019]. Comunidad de Madrid.

${ }^{17}$ Junta de Andalucía. (2016). Plan estratégico de desarrollo de las lenguas en Andalucía [Strategic plan for the development of languages in Andalusia]. Horizonte 2020. Junta de Andalucía. https://bit.ly/2OXiYK5

${ }^{18}$ Council of Europe. (2018a). Application of the European charter for regional or minority languages. Biennial Report by the Secretary General of the Council of Europe to the Parliamentary Assembly Communication Secretary General. Council of Europe.
} 


\section{Figure 1}

Research procedure

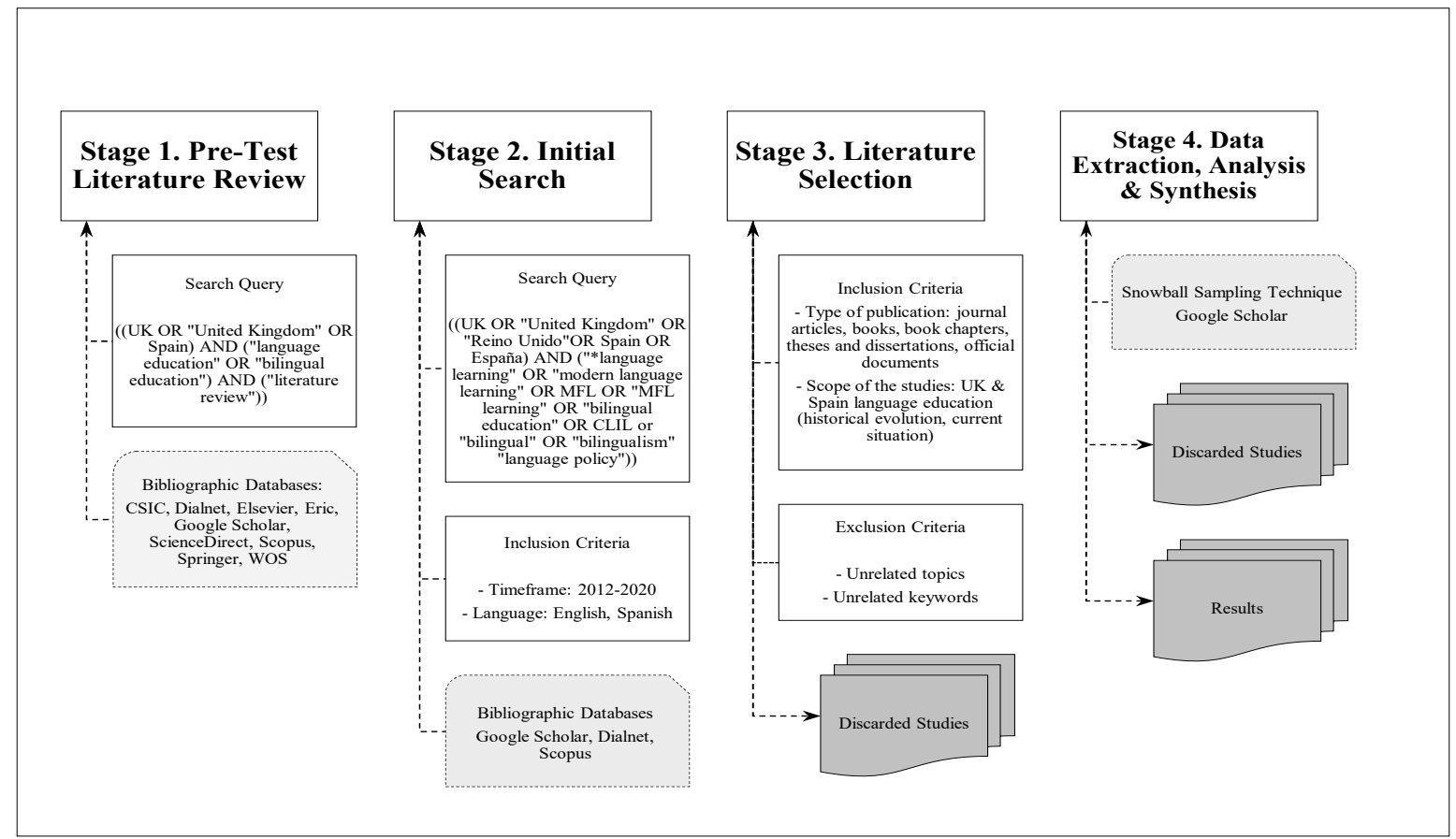

Note. Own elaboration.

\section{Stage 1. Pre-Test Literature Review}

This stage included: (i) checking if previous systematic reviews on the UK's language and bilingual education provision have been carried out; (ii) performing a general search in bibliographic databases (CSIC, Dialnet, Elsevier, Eric, Google Scholar, ScienceDirect, Scopus, Springer, WOS) to measure the estimated size of the documentary corpus; and (iii) identifying keywords to include in the search query.

\section{Stage 2. Initial Search}

In this stage, the research protocol was developed by (a) stating the RQs, (b) creating the search query (Figure 1), (c) identifying relevant bibliographic databases (Google Scholar, Dialnet, and Scopus), (d) establishing the timeframe (2012-2020), and (e) limiting the languages under research (Spanish and English). Afterwards, an initial search was conducted in the identified bibliographic databases to create an initial documentary corpus.

\section{Stage 3. Literature Selection}

This stage included: (i) analysing the titles, abstracts, and keywords of selected papers following inclusion criteria (journal articles, books, book chapters, theses and dissertations, and official documents analysing the historical evolution and the present situation of language and/or bilingual education in the UK and Spain were selected) and exclusion criteria (studies with unrelated topics and/or keywords); and (ii) minimizing bias by having the researchers work independently (the papers were individually analysed by the three researchers to guarantee that all of them were checked multiple times).

\section{Stage 4. Data Extraction, Analysis, and Synthesis}

This stage included: (i) obtaining the full texts from the selected databases, (ii) using Mendeley software to extract data from the full papers and organize detailed bibliographic information; (iii) using the snowball sampling technique to expand the documentary corpus (using Google Scholar to identify related studies that have cited the already selected studies; Jalali \& Wohlin, 2012); (iv) performing a descriptive synthesis to identify categories of analysis (year of publication, authors, countries, and research dimensions); (v) minimizing bias by having the three researchers work co-operatively (the papers were individually analysed by the research team to guarantee they were checked multiple times -attention was paid to the research methods, study focus, 
and findings-; when disagreeing, the team discussed and negotiated until reaching consensus); and (vi) answering the RQs.

Microsoft Excel was employed for analysing information of selected studies, while Bardin's content analysis technique (2013) was applied to categorise the papers and help draw conclusions. Analysis followed reading, analysis, synthesis, deduction, and induction methods to build a well-organised review (Okoli, 2015).

\section{Results and Discussion}

The systematic literature review was carried out from September 2020 to April 2021.

\section{Stage 1. Pre-Test Literature Review}

Initially, the pre-test search query defined in Figure 1 was applied. Four papers reviewing MFL and bilingual education provision in Europe, the UK, and Spain and published between 2012 and 2020 were selected. Since no literature reviews regarding the UK were found, the researchers chose all of the relevant papers analysing either the historical development or provision of language/bilingual education in these contexts. The chosen studies (described below) were analysed to reveal areas of research regarding language/bilingual education that could help refine subsequent searches by identifying relevant keywords.

Izquierdo (2017) presented an in-depth analysis of the origins and evolution of bilingual education in different European countries including Spain, highlighting how the Council of Europe's recommendations have set the path for many educational institutions; the author also highlights the limited presence of bilingual education in the UK. In the context of Spain, González (2015) analysed the factors involved in language learning and educational policies in compulsory education by comparing the situations in Spain and the Netherlands; the author reveals a certain heterogeneity in educational policies and teaching methods, although some differences can be found in terms of institutional initiatives (for instance, in Spain there are more regulations supporting MFL learning and teaching in pre-primary and primary education, while the Netherlands seems to have extensive experience in MFL promotion through secondary education).

The UK's history in language education was discussed by Vidal (2017), McLelland (2018), and Dobson (2018). Vidal (2017) reviewed the main concerns about the drop in the numbers of MFL learners and investigated the factors affecting the uptake of MFLs in secondary education in the UK, pointing out students' feelings of not being good enough at languages as the main cause. McLelland (2018) provided a review of Britain's MFL provision, analysing the history of language learning and teaching, the languages commonly learnt (generally French), and changes that have led to the current situation. Dobson (2018) analysed the provision and evolution of foreign language teaching in England since the 1970s, highlighting issues such as the preponderance of French, German, and Spanish among the range of languages studied, the higher proportion of female students taking MFL lessons as opposed to males, the low take-up rates of languages after the age of 14, the uncertainty of many teachers "about the place of grammar and its relationship to communication" (p. 77), the lack of continuity in the implementation of language policies, and the participation and influence of the UK in European projects, among other aspects.

\section{Stages 2 and 3. Initial Search and Literature Selection}

The initial search allowed the researchers to redefine the search query. With the new query, a total of 116 studies were selected, out of which 11 were discarded due to lack of relevance; thus, the final documentary corpus consisted of 105 papers. Table 1 shows the distribution of selected studies by type and year of publication, including total number and percentage. 
Table 1

Distribution by type and year of publication of studies identified in stage 2

\begin{tabular}{lccccc}
\hline & Book chapters & Articles & Books and others & No. & \% \\
\hline 2012 & 2 & 1 & 1 & 4 & 3.81 \\
2013 & 1 & 1 & 4 & 6 & 5.71 \\
2014 & 1 & 6 & 1 & 8 & 7.62 \\
2015 & 0 & 6 & 4 & 10 & 9.52 \\
2016 & 0 & 5 & 5 & 10 & 9.52 \\
2017 & 5 & 8 & 4 & 17 & 16.19 \\
2018 & 11 & 8 & 9 & 8 & 26.67 \\
2019 & 1 & 2 & 5 & 14 & 7.62 \\
2020 & 1 & 10 & 3 & 105 & 13.33 \\
No. & 22 & 47 & 36 & 100 & 100 \\
\hline
\end{tabular}

Note. Own elaboration.

\section{Stage 4. Data Extraction, Analysis, and Synthesis}

Out of the 105 selected papers, 43 referred to the Spanish context and 62 to the UK, distributed as follows: 18 papers focused on the UK from a general perspective (although many of them devoted significant space to England), 5 analysed the context of Wales, 12 dealt with England, 18 studied Scotland, and 9 referred to Northern Ireland. Below, the main results and findings are described and references to the most significant papers are included.

The UK has been traditionally linked to language diversity since many languages of colonisation, migration, and conquest (e.g., Celtic languages, Latin, Viking, French) have been present in the islands (McLelland, 2018) but also due to the waves of immigration to the UK experienced in the $20^{\text {th }}$ century, which increased the ethnic, cultural, and linguistic diversity of the country (Oakland, 2016). In this sense, it could be said that language learning, yet in an informal way, has never been something unknown in the country. Present trends, however, show an overall decline in the number of students learning languages other than English (Lanvers, 2017a) and, furthermore, language learning beyond the compulsory stages has increasingly become an elitist practice (Lanvers, 2017b).

As for the chosen MFL, it is remarkable that, probably due to the proximity of France, French has remained the 'first' foreign language in primary and secondary schools, although, as McLelland (2018) explains, command of the language is limited. However, Spanish seems to be earning its place among MFL choices in the UK since late $20^{\text {th }}$ century (McLelland, 2017), and nowadays it is attracting more and more students from all across England (Tinsley \& Doležal, 2018), Northern Ireland (Carruthers \& Mainnín, 2018), Scotland (McKelvey, 2017) and Wales (Tinsley, 2018a). German also occupies a privileged position among language choices but, again, it is losing importance due to the rise of Spanish (Collen, 2020; McLelland, 2018).

In relation to methods of teaching, the reality did not differ much from elsewhere in Europe until the end of the $20^{\text {th }}$ century. Grammar-translation methodologies directed language teaching for a long time until the publication of the White Paper on Education and Training and the Common European Framework of Reference for Languages and the communicative turn in language education (Kramsch, 2013, p. 64). The role of the CILT was crucial for the transformation of language provision thanks to its efforts to support and encourage specialised language research, creating materials and curriculum guides to help teachers, monitoring trends in language teaching, and, in sum, offering "a ready-made platform" for teachers all across the country (Dobson, 2018, p. 78). Unfortunately, the work of the CILT came to an end after 2010 with the new Conservative-Liberal Democrat Coalition Government, whose policies led to the creation of a new teaching agency, the transfer of funding from language teaching to general education budgets, and a general loss of supporting infrastructure for language teaching. 
The UK has played an important role in the development of language education in Europe, mainly in the form of collaborations in transnational research projects, although unfortunately such contributions and efforts have not always been translated into consistent language policies in the country. Many scholars (Lanvers, 2017a, 2017b; Smith \& McLelland, 2018; Vidal, 2017) have discussed the reasons that explain the UK's lack of language abilities or interests, and most of them seem to agree on the main one: the rise of Global English. The establishment of their mother tongue as the most used international language leads to native speakers of English believing that language learning is unnecessary (Crystal, 2012; Lanvers, 2014; Lo Bianco, 2014). Additionally, research also points at the uninspiring MFL curricula (Busse \& Walter, 2013, p. 451) and the "English hegemonic perspectives" and "focus on English competencies" that control language policies to the detriment of languages other than English (Lanvers, 2014, p. 151).

The consequences of Brexit have been repeatedly discussed in recent studies (see Broady, 2020). Tinsley (2018b), for example, points at how Brexit could have a devastating effect on language education as the UK would not be able to apply for EU funding aimed at promoting language learning and mobility (e.g., the Erasmus+ program). Holmes (2018) explains how leaving the EU will not only mean an increase in bureaucracy, but also the constant test of the UK's language skills and cultural competence when negotiating with different countries and their corresponding languages and cultures. Indeed, "building a prosperous Britain post-Brexit will depend on capitalising on the knowledge and skills of the labour market, including its ability to speak multiple languages and understand diverse cultures" (Holmes, 2018, p. 64), and based on this premise, the UK's nations seem to be taking action to provide students with a quality environment to develop their language abilities and cultural agility as important employability skills for the $21^{\text {st }}$ century.

In Scotland, the diversity of languages spoken by its population and the official status of English, Gaelic and Scots as home languages have led to the implementation of language policies to provide Scottish citizens with opportunities for MFL learning (McKelvey, 2017). These efforts have not been influenced by Brexit (Doughty \& Spöring, 2018) as the very first attempts to develop quality language policies began in the early 2010s. In this sense, the 1+2 Language Strategy has been implemented since 2011, aiming at ensuring the learning of one MFL from the first year of primary education and a second MFL from the fifth all the way through compulsory education ${ }^{19}$. Unfortunately, there is little evidence about whether the strategy is showing positive results. Gaelic-medium education is provided in some Scottish schools to promote the learning of non-linguistic subjects through Gaelic and revitalise the use of Gaelic (Bòrd na Gàidhlig, 2018; MacLeod \& Smith-Christmas, 2018). As for the use of Scots, the language has received increasing public recognition since 2010 and, consequently, it is starting to be more appreciated as part of Scotland's identity, history, and culture (TNSBMRB, 2010, as cited in Hancock, 2014, p. 173). As for the Scots language, there are no Scots-mediuminstruction programs available at any educational stage, nor official policies or specific references in curricula that regulate its use. In primary education, some features of Scots may be introduced in the study of literature but not as an independent subject. In secondary, the teaching of Scots is normally part of the syllabus of English departments, although some secondary schools are introducing a specific department so as to give students the opportunity to study the history and development of the language. In vocational studies, some teachers may use Scots informally or, on some occasions, deliver their lessons through Scots or a mixture of Scots and English; there are, though, some programs in universities in Aberdeen, Edinburgh, and Glasgow that provide undergraduates with the chance to learn the Scots language, linguistics, and history (Niven, 2017). Scholars have highlighted how local policies have helped revitalize Gaelic and Scots ${ }^{20}$, similarly to what happens in Spain with Basque, Catalan, Valencian, and Galician, or in Finland with Karelian, Sami, and Swedish (Juaristi et al., 2008, as cited in Hancock, 2014, p. 170).

In Wales, the Bilingual plus 1 strategy is the official language policy, a five-year plan that tries to respond to the decline of MFL learners (as in the other nations of the UK) by requiring children learn Welsh and English from the start of school, and one MFL in the fifth year of primary education. It aims at increasing the number of students aged 7-19 studying MFLs (French, German, and Spanish seem to be the most common), as well as at improving language proficiency and the understanding of the value of language learning (Welsh Government, 2015). Despite government efforts, studies reveal that numbers of MFL learners continue to drop (Tinsley,

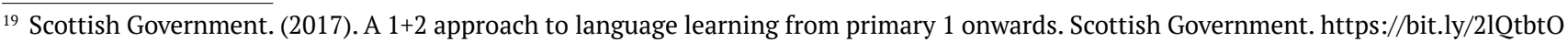

${ }^{20}$ Council of Europe. (2018a). Application of the European charter for regional or minority languages. Biennial Report by the Secretary General of the Council of Europe to the Parliamentary Assembly Communication Secretary General. Council of Europe.
} 
2018a). It is also noteworthy how language policies have contributed to the revitalization of Welsh, especially thanks to the expansion of Welsh-medium education, together with the introduction of the obligatory learning of Welsh from the age of five (Hancock, 2014, p. 171). Three types of bilingual schools can be found in Wales: (i) Welsh-medium schools with a significant use of English, where $50-70 \%$ of the curriculum is taught through Welsh; (ii) English-medium schools with a significant use of Welsh, where a 20-50\% of the curriculum is taught through Welsh; and (iii) dual stream schools, where students opt to be placed in a Welsh-medium group or an English-medium one (Jones, 2017, p. 200).

In England, schools provide 7-to-11-year-old students with up to 60 weekly minutes of MFL learning, with French and Spanish being the main languages taught, although some schools also teach German, Chinese, Latin, or other languages in smaller proportions. In secondary education, few schools offer MFLs other than French, German, or Spanish to 11-to-16-year-old learners, usually in the form of two or three weekly lessons of one hour each (Tinsley, 2019). Concerning bilingual education, there are examples of CLIL implementation in schools in England where interest grew during the 1990s and early 2000s (cf. Coyle, 2013; Dobson, 2020). Nevertheless, as Dobson (2020) explains, developing CLIL in the UK is still a great challenge due to the differences in implementation from that in mainland Europe, where CLIL "is almost synonymous with teaching through the medium of English; no other language has this standing in the UK [...], with the exception of those areas where Gaelic- or Welsh- medium education is well established" (p. 508).

As part of the UK, modern languages education in Northern Ireland is quite similar to that in England and Wales in terms of policy and assessment (Carruthers \& Mainnín, 2018). Some primary schools offered language learning (including Spanish, Irish, French, German, and Mandarin) in early years as part of the Primary Modern Languages Programme (PMLP), which ran from 2007 to 2015. In the majority of primary schools, languages are occasionally taught during class time, often by generalist teachers, although by specialist language teachers as well (British Council Northern Ireland, 2019).

In secondary schools, learning a second language is compulsory for pupils aged 11-14, with French, Spanish, German, and Irish being the most common languages. Since the 1970s, there has been an increase in numbers of schools providing Irish-medium education (Grádaigh, 2015). According to the Department of Education of Northern Ireland (2015), Irish-medium schools can be broadly categorised in three types: (i) schools with full instruction through Irish, with Irish being the medium of instruction for all subjects except for English and another MFLs in secondary education; (ii) partial instruction through Irish, in which students only learn some subjects through Irish and the rest are taught through English (except for the MFL); and (iii) bilingual centres, where both Irish and English are intended to be used equally.

In Spain, as the regions have the freedom to organise their education policies ${ }^{21}$, each one directs its efforts to promote language learning, linguistic diversity, and intercultural awareness by developing CLIL programs. As in the UK, the situation varies from one place to another. From a general perspective, CLIL programs have been implemented since the early 2000s, preceded by Andalusia and Madrid, but also in Catalonia, the Basque Country, and Extremadura, the last regions to develop CLIL (trilingual in the case of Catalonia and the Basque Country). In all of them, English is the most adopted language of instruction (Izquierdo, 2017).

In relation to monolingual regions, CLIL has been implemented since 2005 in Andalusia, with English being the main language of instruction, but with French and German also offered (as established in the Plan Estratégico de Desarrollo de las Lenguas en Andalucía; Junta de Andalucía, 2016). In primary education, arts, physical education, and science are common subjects taught through the MFL. The Canary Islands have implemented CLIL since 2004, and one hour per week of each content subject chosen (except for Spanish, Latin, or religion) is taught in the MFL (English with few exceptions; Gobierno de Canarias ${ }^{22}$ ). CLIL is also being implemented in Extremadura ${ }^{23}$ with English, French, and Portuguese as possible languages of instruction for the teaching of up to two content subjects.

\footnotetext{
${ }^{21}$ Ley Orgánica 9/1992, de 23 de diciembre, de transferencia de competencias a Comunidades Autónomas que accedieron a la autonomía por la vía del artículo 143 de la Constitución. BOE no. 308, 24 December 1992.

${ }^{22}$ Gobierno de Canarias. (2018). Plan de impulso de las lenguas extranjeras [Plan to promote foreign languages]. Gobierno de Canarias.

${ }^{23}$ Orden de 20 de abril de 2017 por la que se regula el programa de Secciones Bilingües en centros docentes sostenidos con fondos públicos de la Comunidad Autónoma de Extremadura y se establece el procedimiento para su implantación en las diferentes etapas educativas. DOE no. 83, 3 May 2017.
} 
In relation to some of the Spanish bilingual regions, three Spanish-Basque bilingual programs have been developed in the Basque Country, where both languages are used to different degrees (Arzoz, 2012); likewise, a trilingual model is also offered with Basque, Spanish, and an MFL (commonly English) as languages of instruction. In Catalonia, CLIL is followed, with an MFL as the language of instruction, including Catalan and Spanish as independent subjects (Gobierno de Cataluña, 2018).

\section{Conclusion}

This paper has examined some similarities and differences between the provision of foreign and bilingual language education in the UK and Spain. It is necessary at this point to answer the research questions of the study. Concerning RQ1 (Which are the main characteristics of the bilingual programs (if any) implemented in the UK?), bilingual education is indeed being implemented in the UK mainly in the form of Irish-, Gaelic- and Welsh-medium education and, in some contexts, in the form of CLIL projects, although CLIL as implemented overseas seems "hardly replicable in the UK" (Dobson, 2018, p. 81). As for RQ2 (What are the similarities and differences between the language policies of the UK and Spain?), language education in the UK is somewhat like that of Spain, as both countries students can learn at least two MFLs; furthermore, CLIL can also be found in the UK, mainly in England. Despite the differences in the way foreign and bilingual language education are provided in both contexts, the UK and Spain do not differ much in theory; in both contexts, for instance, the attempts to foster language proficiency have increased significantly since the 1990s and early 2000s (see Dobson, 2018; McLelland, 2018). In practice, however, more institutional efforts are needed in the UK to overcome the commonly accepted lack of interest in languages and the poor language skills so as to eradicate the 'climate of negativity' and consequent loss of confidence of British learners toward languages (Graham \& Santos, 2015; Schulzke, 2014).

These results and conclusions should be considered in light of two limitations. First, although Spain and the UK share sociocultural similarities, other similar monolingual countries and contexts could be examined in future studies. Second, the number of studies gathered in the literature review could also be expanded in order to draw more conclusions.

This analysis has discussed the differences that exist within the UK in relation to language teaching. These seem to be the result of the freedom of the four nations that comprise the UK to make decisions regarding educational affairs. Language teaching is provided across the UK, whereas bilingual education is offered in the form of Welsh-, Irish-, and Gaelic-medium education mainly, although CLIL (the common approach used in Spain) has been implemented from time to time in England. In any case, more research is still needed in both contexts.

\section{Acknowledgments}

This work has been supported by the Spanish Ministry of Education (Resolución de 5 de diciembre de 2017, de la Secretaría de Estado de Educación, Formación Profesional y Universidades, por la que se convocan ayudas para la formación de profesorado universitario, de los Subprogramas de Formación y de Movilidad incluidos en el Programa Estatal de Promoción del Talento y su Empleabilidad, en el marco del Plan Estatal de Investigación Científica y Técnica y de Innovación 2013-2016) and by the research project "Facing Bilinguals: Study of Bilingual Education Programmes' Results through Social Data Analysis" (EDU2017-84800-R), funded by the Spanish Ministry of Industry and Competitiveness.

\section{Conflicts of interest}

The authors declare that they have no conflicts of interest. 


\section{References}

Arzoz, X. (2012). Basque-medium legal education in the Basque Country. In X. Arzoz (Ed.), Bilingual higher education in the legal context: Group rights, state policies and globalisation (pp. 135-166). Martinus Nijhoff Publishers.

Baker, P., \& Eversley, J. (2000). Multilingual capital: The languages of London's schoolchildren and their relevance to economic, social and educational policies. Battlebridge Publications.

Bardin, L. (2013). L'analyse de contenu [Content analysis]. Presses Universitaires de France. https://doi. org/10.3917/puf.bard.2013.01

Bòrd na Gàidhlig. (2018). National Gaelic language plan 2018-2023. Bòrd na Gàidhlig.

Bower, K. (2021). Content and language integrated learning in England: Missed opportunities and ways forward. In U. Lanvers, A. S. Thompson, \& M. East (Eds.), Language learning in anglophone countries (pp. 267-287). Springer International Publishing. https://doi.org/10.1007/978-3-030-56654-8_14

British Council Northern Ireland. (2019). Language trends Northern Ireland 2019. Findings from surveys of primary and post-primary schools. British Council.

Britton, E. R. (2021). Using critical language awareness to disrupt global English hegemony in US higher education. In U. Lanvers, A. S. Thompson, \& M. East (Eds.), Language learning in Anglophone countries (pp. 425-443). Palgrave Macmillan. https://doi.org/10.1007/978-3-030-56654-8_21

Broady, E. (2020). Language learning in the UK - taking stock. The Language Learning Journal, 48(5), 501507. https://doi.org/10.1080/09571736.2020.1812812

Busse, V., \& Walter, C. (2013). Foreign language learning motivation in higher education: A longitudinal study of motivational changes and their causes. The Modern Language Journal, 97(2), 435-456. https://doi. org/10.1111/j.1540-4781.2013.12004.x

Carruthers, J., \& Mainnín, M. B. Ó. (2018). Languages in Northern Ireland: Policy and practice. In M. Kelly (Ed.), Languages after Brexit. How the UK speaks to the world (pp.159-172). Springer International Publishing. https:// doi.org/10.1007/978-3-319-65169-9_14

Cenoz, J., Genesee, F., \& Gorter, D. (2014). Critical analysis of CLIL: Taking stock and looking forward. Applied Linguistics, 35(3), 243-262. https://doi.org/10.1093/applin/amt011

Collen, I. (2020). Language Trends 2020. Language teaching in primary and secondary schools in England. British Council. https://bit.ly/3wnPvuG

Coyle, D. (2013). Listening to learners: An investigation into "successful learning" across CLIL contexts. International Journal of Bilingual Education and Bilingualism, 16(3), 244-266. https://doi.org/10.1080/136700 50.2013.777384

Coyle, D., Hood, P., \& Marsh, D. (2010). CLIL: Content and language integrated learning (3 ${ }^{\text {rd }}$ ed.). Cambridge University Press.

Crystal, D. (2012). English as a global language (2 ${ }^{\text {nd }}$ ed.). Cambridge University Press. https://doi.org/10.1017/ CBO9781139196970

Dalton-Puffer, C., \& Smit, U. (2013). Content and language integrated learning: A research agenda. Language Teaching, 46(4), 545-559. https://doi.org/10.1017/S0261444813000256

Dobson, A. (2018). Towards "MFL for All" in England: A historical perspective. The Language Learning Journal, 46(1), 71-85. https://doi.org/10.1080/09571736.2017.1382058

Dobson, A. (2020). Context is everything: Reflections on CLIL in the UK. The Language Learning Journal, 48(5), 508-518. https://doi.org/10.1080/09571736.2020.1804104

Dobson, A., Pérez, M. D., \& Johnstone, R. (2010). Bilingual education project Spain. Evaluation report. Findings of the independent evaluation of the Bilingual Education Project Ministry of Education (Spain) and British Council (Spain). British Council and Ministry of Education.

Doughty, H., \& Spöring, M. (2018). Modern languages in Scotland in the context of Brexit. In M. Kelly (Ed.), Languages after Brexit. How the UK speaks to the world (pp. 137-147). Palgrave Macmillan. https://doi. org/10.1007/978-3-319-65169-9_12

Dunlevy, D. A. (2020). Learning Irish amid controversy: How the Irish Language Act debate has impacted learners of Irish in Belfast. Journal of Multilingual and Multicultural Development, 1-16. https://doi.org/10.1080/0143 4632.2020.1854272

Escolano, X. (2021). Cultural identity and Catalan language planning. In A. Cortijo-Ocaña, \& V. Martines (Eds.), History of Catalonia and its implications for contemporary nationalism and cultural conflict (pp. 214-227). IGI Global. https://doi.org/10.4018/978-1-7998-6614-5.ch015

García, O. (2009). Bilingual education in the $21^{\text {st }}$ century: A global perspective. Wiley-Blackwell. 
Gobierno de Cataluña. (2018). El modelo lingüístico del sistema educativo de Cataluña. El aprendizaje y el uso de las lenguas en un contexto educativo multilingüe y multicultural [The linguistic model of the Catalan educational system. Language learning and use in a multilingual and multicultural educational context]. Gobierno de Cataluña.

González, M. (2015). La enseñanza de las lenguas extranjeras en España y Holanda. Un estudio comparado [The teaching of foreign languages in Spain and Holland. A comparative study] [Unpublished $\mathrm{PhD}$ thesis]. Universidad Complutense de Madrid.

Grádaigh, S. Ó. (2015). Who are qualified to teach in second-level Irish-medium schools? Irish Educational Studies, 34(2), 165-182. https://doi.org/10.1080/03323315.2015.1025533

Graham, S., \& Santos, D. (2015). Language learning in the public eye: An analysis of newspapers and official documents in England. Innovation in Language Learning and Teaching, 9(1), 72-85. https://doi.org/10.1080/1 7501229.2014.995766

Hancock, A. (2014). Language education policy in multilingual Scotland: Opportunities, imbalances and debates. Language Problems and Language Planning, 38(2), 167-191. https://doi.org/10.1075/lplp.38.2.04han

Holmes, B. (2018). Speaking to a global future: The Increasing value of language and culture to British business post-Brexit. In M. Kelly (Ed.), Languages after Brexit. How the UK speaks to the world (pp. 61-74). Palgrave Macmillan. https://doi.org/10.1007/978-3-319-65169-9_6

Horner, K., \& Weber, J. J. (2015). Multilingual education in the politics of language in Luxembourg. In C. Peersman, G. J. Rutten, \& R. Vosters (Eds.), Past, present and future of a language border: Germanic-Romance encounters in the low countries (pp. 233-254). De Gruyter Mouton.

Izquierdo, E. (2017). Origen, causas y evolución de la educación bilingüe: El caso de Estados Unidos, Canadá y España [Origin, causes and evolution of bilingual education: The case of the United States, Canada and Spain] [Unpublished PhD thesis]. Universidad Rey Juan Carlos. https://bit.ly/2nECazh

Jalali, S., \& Wohlin, C. (2012). Systematic literature studies: Database searches vs. backward snowballing. In P. Runeson, M. Höst, E. Mendes, A. Andrews, \& R. Harrison (Eds.), ESEM '12 2012 ACM-IEEE International Symposium on Empirical Software Engineering and Measurement Lund (pp. 29-38). ACM.

Jones, B. (2017). Translanguaging in bilingual schools in Wales. Journal of Language, Identity \& Education, 16(4), 199-215. https://doi.org/10.1080/15348458.2017.1328282

Kelly, M. (2018). Why are many people resistant to other languages? In M. Kelly (Ed.), Languages after Brexit. How the UK speaks to the world (pp. 13-24). Palgrave Macmillan. https://doi.org/10.1007/978-3-319-65169-9_2

Kitchenham, B., Brereton, O. P., Budgen, D., Turner, M., Bailey, J., \& Linkman, S. (2009). Systematic literature reviews in software engineering - A systematic literature review. Information and Software Technology, 51(1), 7-15. https://doi.org/10.1016/j.infsof.2008.09.009

Kramsch, C. (2013). Culture in foreign language teaching. Iranian Journal of Language Teaching Research, 1(1), $57-78$.

Lanvers, U. (2014). On the predicaments of the English L1 language learner: A conceptual article. International Journal of Applied Linguistics, 26(2), 147-167. https://doi.org/10.1111/ijal.12082

Lanvers, U. (2017a). Contradictory others and the habitus of languages: Surveying the L2 motivation landscape in the United Kingdom. Modern Language Journal, 101(3), 517-532. https://doi.org/10.1111/modl.12410

Lanvers, U. (2017b). Elitism in language learning in the UK. In D. J. Rivers \& K. Zotzmann (Eds.), Isms in language education: Oppression, intersectionality and emancipation (pp. 50-73). De Gruyter.

Lanvers, U., \& Coleman, J. A. (2017). The UK language learning crisis in the public media: A critical analysis. The Language Learning Journal, 45(1), 3-25. https://doi.org/10.1080/09571736.2013.830639

Lo Bianco, J. (2014). Domesticating the foreign: Globalization's effects on the place/s of languages. Modern Language Journal, 98(1), 312-325. https://doi.org/10.1111/j.1540-4781.2014.12063.x

MacLeod, M., \& Smith-Christmas, C. (2018). The future of Gaelic language revitalisation in Scotland. In M. MacLeod, \& C. Smith-Christmas (Eds.), Gaelic in contemporary Scotland: The revitalisation of an endangered language (pp. 173-182). Edinburgh University Press.

MacQuarrie, S., \& Lyon, F. (2019). A consideration of the inequalities apparent in Gaelic medium education linked to appropriate language assessment: An Outline of the field and potential future directions. Educational Review, 71(3), 350-361. https://doi.org/10.1080/00131911.2017.1417236

McKelvey, R. (2017). Language provision in education: A view from Scotland. Social Inclusion, 5(4), 78-86. https:// doi.org/10.17645/si.v5i4.1150

McLelland, N. (2017). Teaching and learning foreign languages. A history of language education, assessment and policy in Britain. Routledge.

McLelland, N. (2018). The history of language learning and teaching in Britain. The Language Learning Journal, 
46(1), 6-16. https://doi.org/10.1080/09571736.2017.1382052

Mehisto, P., \& Genesee, F. (2015). Building bilingual education systems: Forces, mechanisms and counterweights. Cambridge University Press.

Niven, L. (2017). Scots: The Scots language in education in Scotland. Mercator European Research Centre on Multilingualism and Language Learning.

Oakland, J. (2016). British civilization. An introduction ( $8^{\text {th }}$ ed.). Routledge.

Okoli, C. (2015). A guide to conducting a standalone systematic literature review. Communications of the Association for Information Systems, 37(43), 879-910. https://doi.org/10.17705/1CAIS.03743

Pérez-Cañado, M. L. (2012). CLIL research in Europe: Past, present, and future. International Journal of Bilingual Education and Bilingualism, 15(3), 315-341. https://doi.org/10.1080/13670050.2011.630064

Relaño-Pastor, A. M. (2015). The commodification of English in "Madrid, comunidad bilingüe": Insights from the CLIL classroom. Language Policy, 14, 131-152. https://doi.org/10.1007/s10993-014-9338-7

Schulzke, M. (2014). The prospects of Global English as an inclusive language. Globalizations, 11(2), 225238. https://doi.org/10.1080/14747731.2014.904173

Smith, R., \& McLelland, N. (2018). Histories of language learning and teaching in Europe. The Language Learning Journal, 46(1), 1-5. https://doi.org/10.1080/09571736.2017.1382051

Smolcic, E., \& Katunich, J. (2017). Teachers crossing borders: A review of the research into cultural immersion field experience for teachers. Teaching and Teacher Education, 62(1), 47-59. https://doi.org/10.1016/j. tate.2016.11.002

Tinsley, T. (2018a). Language trends Wales 2018. The state of language learning in secondary schools in Wales. British Council Wales. https://bit.ly/2M8bOOQ

Tinsley, T. (2018b). Languages in English secondary schools post-Brexit. In M. Kelly (Ed.), Languages after Brexit. How the UK speaks to the world (pp. 127-136). Springer International Publishing. https://doi.org/10.1007/9783-319-65169-9_11

Tinsley, T. (2019). Language Trends 2019. Language Teaching in Primary and Secondary Schools in England. Survey Report. British Council. https://bit.ly/2Yw4eCz

Tinsley, T., \& Board, K. (2013). Languages for the Future. Which Languages the UK Needs Most and Why. British Council. https://bit.ly/33mVTTt

Tinsley, T., \& Doležal, N. (2018). Language trends 2018. Language teaching in primary and secondary schools in England. British Council. https://bit.ly/30Esin6

Vidal, C. (2017). The study of foreign languages in England: Uptake in secondary school and progression to higher education. Language, Culture and Curriculum, 30(3), 231-249. https://doi.org/10.1080/07908318.201 7.1306069 